\title{
IMPLEMENTASI METODE SIMPLE ADDITIVE WEIGHTING(SAW) UNTUK EVALUASI KINERJA DOSEN PADA STMIK BINA MULIA PALU
}

\author{
Dewi Kusumawati ${ }^{1}$,Siti Nurhayati ${ }^{2}$ dan Fitriyanti Andi Masse ${ }^{3}$ \\ Teknik Informatika STMIK BINA MULIA Palu, Indonesia ${ }^{1}$ \\ Sistem Informasi Universitas Yapis Papua Jayapura, Indonesia ${ }^{2}$ \\ Sistem Informasi STMIK BINA MULIA Palu, Indonesia ${ }^{3}$ \\ Email: ${ }^{1}$ raihansu1006@gmail.com,${ }^{2}$ nurhayatist.siti21@gmail.com, ${ }^{3}$ fitriyntam@gmail.com
}

\begin{abstract}
Abstrak
Dosen yang kapasitasnya sebagai seorang pendidik di lingkungan perguruan tinggi memegang peran utama dalam proses belajar mengajar, dosen sangat menentukan perkembangan dan kemampuan siswa di bidang ilmu pengetahuan dan teknologi, lembaga pendidikan yang dalam ini merupakan induk kerja dari para dosen, sangat berkepentingan dalam menjaga mutu para dosen. Tujuan penelitian ini adalah untuk menjaga mutu dosen dalam proses belajar mengajar dengan melakukan penilain evaluasi kinerja dengan membagun sebuah aplikasi Sistem Pendukung Keputusan, dalam aplikasi ini metode yang digunakan untuk mendukung penilaian evaluasi kinerja dosen adalah Simple Additive Weighting (SAW). Sistem pendukung keputusan ini menggunakan metode pengembangan sistem model waterfall. Ada lima kriteria penilaian yang digunakan dalam penelitian ini yakni, (1) Penguasaan dan kemampuan dalam menjelaskan, (2) Kemampuan dalam menjawab pertanyaan, (3) Kemampuan dalam memberi motivasi mahasiswa, (4) Kemampuan membuat suasana kelas menyenangkan, (5) Kedisiplinan hadir dalam perkuliahan. Hasil penelitian dapat mendukung keputusan pada penilaian evaluasi kinerja dosen menggunakan kriteria yang telah ditentukan dan proses lain yang terkait dalam penilaian evaluasi kinerja dosen.
\end{abstract}

Kata-kunci : sistem pendukung keputusan, evaluasi kinerja dosen, simple additive weightingIntroduction

\begin{abstract}
Lecturers whose capacity as an educator in a university environment plays a major role in the teaching and learning process, lecturers greatly determine the development and abilities of students in the field of science and technology, educational institutions which are the parent work of lecturers, are very interested in overseeing the quality lecturer. The purpose of this study is to maintain the quality of teaching in the teaching and learning process by evaluating performance by building a Decision Support System application, in the application the method used to support the evaluation of teacher performance evaluation is Simple Additive Weighting (SAW). This decision support system uses the waterfall model system development method. There are five criteria used in this thesis, (1) Mastery and ability to explain, (2) Ability to answer questions, (3) ability to motivate students, (4) ability to create a pleasant classroom atmosphere, (5) Discipline present in lectures. The results of the study can support the decision to evaluate the performance appraisal in accordance with the specified criteria and other processes involved in evaluating lecturer performance.
\end{abstract}

Keywords: support system, lecturer performance evaluation, simple additive weighting

\section{PENDAHULUAN}

Salah satu upaya lembaga Pendidikan Tinggi untuk menjamin kualitas lulusan dan proses belajar mengajar adalah dengan meningkatkan kualitas kinerja dosen dalam proses belajar mengajar. Kualitas lembaga pendidikan ditentukan oleh minimal tiga faktor yakni mahasiswa, dosen dan fasilitas sarana belajar mengajar, ketiga faktor ini saling berkaitan dan saling mendukung antara satu dengan yang lain dalam menciptakan proses belajar yang baik. Dosen adalah seseorang yang berdasarkan pendidikan dan keahliannya diangkat oleh lembaga perguruan tinggi dengan tugas utama mengajar.Menurut UU No 14 tahun 2005dosen adalah pendidik profesional dan ilmuwan dengan tugas utama mentransformasikan, mengembangkan, dan menyebarluaskan ilmu pengetahuan, teknologi, dan seni melalui pendidikan, penelitian dan pengabdian kepada masyarakat.

Penilaian kinerja Dosen dalam suatu Perguruan Tinggi merupakan suatu kegiatan mengevaluasi kinerja dosen yang ada dalam Perguruan Tinggi. Secara umum manfaat penilaian kinerja adalah mengelolah operasi organisasi secara efektof dan efesien melaluai pemotivasian personil secara maksimal, membantu pengambilam keputusan yang berkaitan dengan penghargaan personel, mengidentifikasi kebutuhan dan 
pengembangan personel dan menyediakan suatu dasar untuk menditribusikan penghargaan [1]

STMIK Bina Mulia Palu belum pernah mengadakan evaluasi kinerja dosen disetiap akhir semester. Maka dari itu evaluasi kinerja dosen di STMIK Bina Mulia Palu dapat dilaksanakan setiap akhir semester dengan membagikan kuesioner evaluasi kinerja dosen kepada mahasiswa, dan selama ini majemen pada STMIK Bina Mulia Palu melakukan penilaian bersifat subyektif dengan keadaan yang sebenarnya, sehingga tidak dapat digunakan sebagai dasar pengambilan keputusan. Untuk penyelesaian masalah dibutuhkan suatu Sistem Pendukung KeputusanSimple Additive Weighting (SAW) untuk menentukan evaluasi kinerja dosen dan membantu dalam proses pengolahan data dan memperbaiki kekurangan seperti kesalahan dalam perhitungan dan dalam penyajian laporan.

Metode yang akan digunakan dalam penelitian ini adalah Simple Additive Weighting (SAW) merupakan metode penjumlahan terbobot dari rating kinerja pada setiap alternatife [2].Dengan konsep dasar mencari penjumlahan terbobot dari rating kinerja pada setiap alternative pada semua atribut.penelitian menggunakan multikriteria untuk evaluasi kinerja dosen, diantaranya,(1) Penguasaan dan kemampuan dalam menjelaskan, (2) Kemampuan dalam menjawab pertanyaan,

Kemampuan dalam memberi motivasi mahasiswa, (4) Kemampuan membuat suasana kelas menyenangkan, (5) Kedisiplinan hadir dalam perkuliahan.

Penelitian mengenai Sistem Pendukung Keputusan Evaluasi Kinerja Dosen dengan Menggunakan Metode Technique For Order By Similarity To Ideal Solution (TOPSIS) dan Preference Rangking Organisation For Evaluation (PROMETHEE), Penelitian ini menghasilkan Sistem Pendukung Keputusan untuk pengelolaan data yang dilakukan oleh Tim Penjaminan Mutu dengan memasukkan tujuh kriteria yang meliputi kusioner, kehadiran dosen, ketepatan waktu pengumpulan soal, ketepatan waktu pengumpulan nilai, jumlah penelitian yang dihasilkan, jumlah jumlah pengabdian masyarakat yang dihasilkan dan partisipasi dosen dalam seminar, yang dapat menghasilkan penentuan peringkat yang dapat membantu TIM Penjaminan Mutu dalam menentukan Dosen yang berpretasi [3].

Penelitian lainnya mengenai Penerapan Metode Simple Additive Weighting (SAW) dalam Penentuan Fakultas Terbaik.Dalam penelitian ini, metode SAW digunakan untuk menganalisis fakultas terbaik di Universitas sebanyak 8 data fakultas yakni Fakultas Pertanian, Fakultas Hukum, Fakultas Agama, Fakultas Ekonomi, Fakultas Ilmu Komputer, Fakultas Teknik, Fakultas Teknologi Industri, dan Fakultas Sastra pada Universitas
Muslim Indonesia berdasarkan 6 kriteria yakni Pelayanan, Sarana dan Prasarana, Kemampuan Dosen, Kebersihan, Biaya Kuliah dan Keaktifan Fakultas. Dari penelitian yang telah dilakukan, sebanyak 40 data penilaian mahasiswa terhadap fakultas yang kemudian diolah menggunakan perhitungan metede SAW sehingga diperoleh hasil akhir Fakultas Teknologi Industri merupakan fakultas terbaik dengan bobot nilai akhir 0.95 [4].

Selain itu, penelitian mengenai Sistem Pendukung Keputusan Kinerja Dosen Menggunakan Metode Weighted Product (Studi Kasus : Fakultas Teknik Universitas Islam Syekh-Yusuf Tanggerang). Penelitian ini menggunakan Metode Weighted Productyang merupakan metode pengambilan keputusan menggunakan perkalian untuk menghubungkan nilai atribut (kriteria), dimana setiap atribut harus harus dipangkatkan dulu dengan bobot atribut (kriteria) yang bersangkutan, dan membantu dalam pengambilan keputusan untuk menentukan penilaian kinerja dosen lebih efisien sehingga keetua jurusan lebih cepat mendapatkan informasi tentang kinerja Dosen [5].

\section{LANDASAN TEORI}

\section{A. Kinerja Dosen}

Kinerja dosen itu sendiri adalah bagaimana seseorang melaksanakan pekerjaannya atau unjuk kerja. Kata unjuk kerja menggambarkan bahwa kinerja individu dapat dilihat dari semangat atau keseriusan individu dalam melaksanakan tugas yang dibebankan kepadanya. Berdasarkan definisi tersebut kinerja dosen adalah kegiatan seseorang dosen melaksanakan pekerjaannya atau unjuk kerja. Kinerja dosen dapat dilihat dari semangatnya dalam melaksanakan tugas tridarma perguruan tinggi yang dibebankan kepadanya[6].

Faktor-Faktor Penentu Kinerja Dosen, keberadaan dosen dalam melaksanakan tugas dan kewajibannya tidak lepas dari pengaruh faktor internal maupun faktor eksternal yang membawa dampak pada perubahan kinerja dosen Faktor-faktor yang mempengaruhi kinerja dosen yaitu sebagai berikut [6].
a) Kepribadian dan Dedikasi
b) Pengembangan Profesi
c) Kemampuan Mengajar
d) Antar Hubungan dan Komunikasi
e) Hubungan Dengan Masyarakat
f) Kedisiplinan
g) Kesejahteraan
h) Iklim kerja 


\section{B. Simple Additive Weighting}

Simple Additive Weighting (SAW) dikenal dengan istilah metode penjumlahan terbobot. Konsep dasar metode SAW adalah mencari penjumlahan terbobot dari rating kinerja setiap alternatif pada semua atribut. Metode SAW membutuhkan proses normalisasi matriks keputusan (X) ke suatu skala yang dapat diperbandingkan dengan semua rating[2].

$r i j=\frac{x i j}{M a x X i j}$ jika $\mathrm{j}$ adalah atribut keuntungan (benefit) ...(1)

$$
r i j=\frac{M i n X i j}{X i j} . \text { jika j adalah atribut biaya (Cost) } \ldots \text { (2) }
$$

Keterangan:

rij : Rating kinerja ternormalisasi

Maxi : Nilai maksimum dari setiap baris dan kolom

Mini : Nilai minimum dari setiap baris dan kolom

Xij : Baris dan kolom dari matriks

rij adalah rating kinerja ternormalisasi dari alternatif $\mathrm{Ai}$ pada atribut $\mathrm{Cj} ; \mathrm{i}=1,2, \ldots, \mathrm{m}$ dan $\mathrm{j}=1,2, \ldots, \mathrm{n}$.

Nilai preferensi untuk setiap alternatif (Vi) diberikan sebagai:

$V_{i=} \sum_{j=1}^{n} W j r i j$

Keterangan:

Vi : Nilai akhir dari alternatif

Wi : Bobot yang telah ditentukan

Rij : Normalisasi matriks

Nilai Vi yang lebih besar mengindikasikan bahwa alternatif Ai lebih terpilih.

Tahapan algoritma Simple Addative Weightsepertipada gambar1.

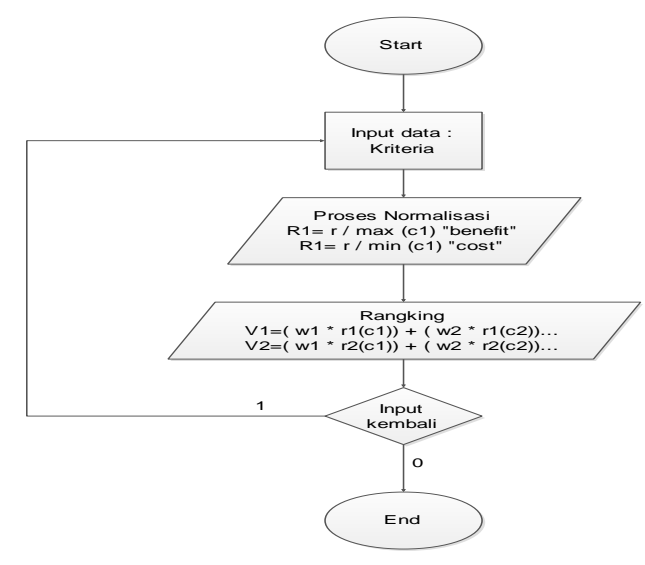

Gambar 1. Flowchart Alur dari metode Simple Addative Weight

\section{METODE PENELITIAN}

A.Jenis penelitian

Jenis penelitian yang digunakan dalam penelitian ini adalah penelitian kuantitatif dengan pendekatan deskriptif. Metode penelitian kuantitatif merupakan salah satu jenis penelitian yang spesifikasinya adalah sistematis, terncana dan terstruktur dengan jelas sejak awal hingga pembuatan desain penelitiannya secara garis besar tahapan penelitian dapat dilihat pada Gambar 2 [7].

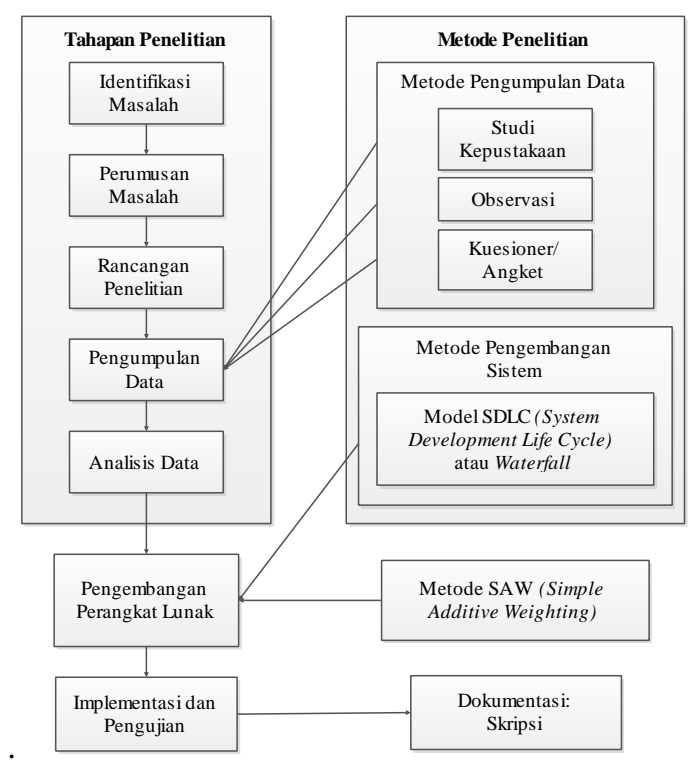

Gambar 2. Diagram alir penelitian

\section{B. Teknik Pengumpulan Data}

Teknik pengumpulan data dapat dilakukan dengan studi kepustakaan, wawancara, dan angket . Pada penelitian ini, peneliti menggunakan angket dengan bentuk rating scale, yaitu memberikan pertanyaan tertutup kepada responden untuk menilai sistem yang telah dirancang dengan 5 pilihan jawaban, yaitu: sangat baik, baik, cukup, kurang dan sangat kurang. Analisa data yang berasal dari kuesioner ber-rating 1 sampai 5 . Diasumsikan skor dari jawaban pertanyaan tersebut, sebagai berikut: a. "Sangat Baik", menunjukan gradasi nilai paling tinggi yaitu 5. b. "Baik", nilai yang lebih rendah dari "Sangat Baik", yaitu 4. c. "Cukup", berada ditingkat lebih rendah dari "Baik", bernilai 3. d. "Kurang" nilai lebih rendah dari "Cukup" yaitu 2. e. "Sangat Kurang" menunjukan gradasi nilai paling rendah, bernilai 1 . 


\section{Uji Validitas dan Reliabilitas}

\section{Uji Validitas}

Uji validitas digunakan untuk mengukur sah atau tidaknya suatu kuesioner. Suatu kuesioner dikatakan valid jika pada kuesioner mampu mengungkapkan suatu yang akan diukur oleh kuesioner tersebut. Pengujian validitas ini menggunakan Pearson Correlation yaitu dengan cara menghitung korelasi antara nilai yang diperoleh dari pertanyaan-pertanyaa. Suatu pertanyaan dinyatakan valid jika tingkat signifikansinya berada dibawah 0,05[7].

\section{Uji Reliabilitas}

Uji reliabilitas sebenarnya adalah alat ukur mengukur suatu kuesioner yang merupakan indikator dari variabel atau kosntruk.Suatu kuesioner dikatakan reliabel atau handal jika jawaban seseorang terhadap pertanyaan adalah konsisten atau stabil dari waktu ke waktu. Butir kuesioner dikatakan reliabel (layak) jika Cronbach's Alpha $>0,06$ dan dinyatakan tidak reliabel jika Cronbach's Alpha<0,06[7].

\section{D.Metode Analisa Data}

Setelah data diperoleh, selanjutnya data dianalisa. Untuk menganalisa data dari angket, dilakukan langkah-langkah sebagai berikut:

a. Angket yang telah diisi responden, diperiksa kelengkapan jawabannya, kemudian disusun sesuai kode responden

b. Mengkuantitatifkan jawaban setiap pertanyaan dengan memberi skor sesuai bobot yang telah ditentukan sebelumnya

c. Membuat tabulasi data

d. Menghitung prosentase tiap sub variable dengan rumus :

Keterangan :

$$
\%=\frac{n}{N} \times 100 \%
$$

$\%=$ Presentase sub variabel

$\mathrm{n}=$ Jumlah skor tiap variabel

$\mathrm{N}=$ Jumlah skor maksimum

e. Berdasarkan presentase yang telah diperoleh kemudian ditransformasikan ke dalam tabel agar pembacaan penelitian menjadi mudah.

Untuk menentukan kriteria kualitatif dilakukan dengan cara :

1) Menentukan presentase skor ideal (skor maksimum)

$$
\frac{5}{5} \times 100 \%=100 \%
$$

2) Menentukan presentase skor terendah (skor minimum)

$$
\frac{1}{5} \times 100 \%=20 \%
$$

3) Menentukan range $=100-20=80$

4) Menentukan interval yang dikehendaki $=5$ (Sangat Baik, Baik, Cukup, Kurang, Sangat Kurang)

5) Menentukan lebar interval =

$$
\frac{80}{5}=16
$$

Berdasarkan perhitungan di atas, maka range persentase dan kriteria kualitatif dapat ditetapkan pada tabel 1 berikut:

Tabel 1.Range Presentase dan Kriteria Kualitatif

\begin{tabular}{|c|l|l|}
\hline No & \multicolumn{1}{|c|}{ Interval } & \multicolumn{1}{c|}{ Kriteria } \\
\hline 1 & $85 \% \geq$ skor $\leq 100 \%$ & Sangat Baik \\
\hline 2 & $69 \% \geq$ skor $\leq 84 \%$ & Baik \\
\hline 3 & $53 \% \geq$ skor $\leq 68 \%$ & Cukup \\
\hline 4 & $37 \% \geq$ skor $\leq 52 \%$ & Kurang \\
\hline 5 & $20 \% \geq$ skor $\leq 36 \%$ & Sangat Kurang \\
\hline
\end{tabular}

E. Metode Pengembangan Sistem

Metode yang digunakan untuk membangun sistem adalah Model Waterfall. Model waterfall menyediakan pendekatan alur hidup perangkat lunak secara sekuensial atau terurut di mulai dari analisis, desain, pengodean, pengujian dan tahapan pemeliharaan (maintenance) [8].

\section{BAB IV HASIL DAN PEMBAHASAN}

\section{A. Analisis Data}

Analisis data dibagi menjadi dua yaitu Data input dan Data output. Data Input antara lain data dosen,data hasil kuesioner, dan perhitungan nilai dari kriteria-kriteria yang ditetapkan. Laporan data output antara lain dosen terbaik pilihan mahasiswa.

\section{B. Analisis Model}

Analisis Model menggunakan Simple Additive Weighting (SAW) atau penjumlahan terbobot. $\mathrm{N} 1=0,30$, $\mathrm{N} 2=0,15, \mathrm{~N} 3=0,05, \mathrm{~N} 4=0,25, \mathrm{~N} 5=0,25$. Dalam proses perhitungannya, penilaian dalam bentuk huruf tersebut dikonversi terlebih dahulu menjadi $\mathrm{A}=5, \mathrm{~B}=4, \mathrm{C}=3, \mathrm{D}$ $=2, \mathrm{E}=1$

Ada 10 pertanyaan dari lima indikator penilaian yang dibagikan kepada mahasiswa untuk dilakukan penilaian kemudian dilakukan perhitungan menggunakan aplikasi SPSS.

\section{Proses SPK}

Penentuan Evaluasi kinerja dosen menggunakan hasil kuisoner yang dimasukkan kedalam matrik pada metode Simple Additive Weighting (SAW) dengan tahapan sebagai berikut :

a. Variabel alternative terdiri dari lima dosen yang di nilai yaitu : 
A1 :Dosen 1

A2 :Dosen 2

A3 :Dosen 3

A4 :Dosen 4

A5 :Dosen 5

b. Variabel Indikator terdiri dari pertanyaan yaitu :

$\mathrm{C} 1$ :Penguasaan dan kemampuan dalam menjelaskan.

$\mathrm{C} 2$ :Kemampuan dalam menjawab pertanyaan.

C3: Kemampuan memberi motivasi mahasiswa

C4: Kemampuan membuat suasana kelas Menyenangkan.

C5 :Kedisiplinan hadir dalam Perkuliahan.

c. Menentukan skala likert atau tingkat kepentingan dari setiap indikator dengan nilai:

$\begin{array}{ll}\text { Sangat baik } & =5 \\ \text { Baik } & =4 \\ \text { Cukup } & =3 \\ \text { Kurang } & =2 \\ \text { Sangat Kurang } & =1\end{array}$

Bobot preferensi atau tingkat kepentingan dari setiap indikator, diberikan nilai pada setiap indikator $(0.30,0.15,0.05,0.25,0.25)$.

Sebagai contohperhitungan setelah di lakukan penilaian kinerja didapatkan skor pada tabel2.

Tabel 3. Alternatif Pilihan dan Nilai

\begin{tabular}{|c|c|c|c|c|c|}
\hline \multirow{2}{*}{ Alternatif } & \multicolumn{5}{|c|}{ Kriteria } \\
\cline { 2 - 6 } & C1 & C2 & C3 & C4 & C5 \\
\hline A1 & 5 & 4 & 4 & 3 & 4 \\
\hline A2 & 5 & 4 & 3 & 3 & 4 \\
\hline A3 & 4 & 4 & 3 & 4 & 4 \\
\hline A4 & 5 & 4 & 3 & 4 & 5 \\
\hline A5 & 4 & 4 & 4 & 4 & 4 \\
\hline
\end{tabular}

d. Membuat matrik keputusan dari skor pembobotan dari setiap alternatif dari setiap indikator :

$$
X=\left[\begin{array}{lllll}
5 & 4 & 4 & 3 & 4 \\
5 & 4 & 3 & 3 & 4 \\
4 & 4 & 3 & 4 & 4 \\
5 & 4 & 3 & 4 & 5 \\
4 & 4 & 4 & 4 & 4
\end{array}\right]
$$

e. Melakukan proses normalisasi matrik ( Rij )

$$
\begin{aligned}
& \mathrm{r} 11=\frac{5}{\max \{5 ; 5 ; 4 ; 5 ; 4\}}=\frac{5}{5}=1 \\
& \mathrm{r} 21=\frac{5}{\max \{5 ; 5 ; 4 ; 5 ; 4\}}=\frac{5}{5}=1
\end{aligned}
$$

$$
\begin{aligned}
& r 31=\frac{4}{\max \{5 ; 5 ; 4 ; 5 ; 4\}}=\frac{4}{5}=0,8 \\
& r 41=\frac{5}{\max \{5 ; 5 ; 4 ; 5 ; 4\}}=\frac{5}{5}=1 \\
& r 51=\frac{4}{\max \{5 ; 5 ; 4 ; 5 ; 4\}}=\frac{4}{5}=0,8 \\
& \text { dst. }
\end{aligned}
$$

f. Membentuk matrik ternomalisasi

$$
R-\left[\begin{array}{lllll}
1 & 1 & 1 & 0,75 & 0,8 \\
1 & 1 & 0,75 & 0,75 & 0,8 \\
0,8 & 1 & 0,75 & 1 & 0,8 \\
1 & 1 & 0,75 & 1 & 1 \\
0,8 & 1 & 1 & 1 & 0,8
\end{array}\right]
$$

g. Proses perangkingan dengan menggunakan bobot yang telah ditentukan oleh pegambil keputusan :

$$
\begin{aligned}
& \text { A1 }=\{(0,30)(1)+(0,15)(1)+(0,05)(1)+ \\
& (0,25)(0,75)+(0,25)(0,8)\}=0,8875 \\
& \text { A2 }=\{(0,30)(1)+(0,15)(1)+(0,05)(0,75)+ \\
& (0,25)(0,75)+(0,25)(0,8)\}=0,875 \\
& \text { A3 }=\{(0,30)(0,8)+(0,15)(1)+(0,05)(0,75)+ \\
& (0,25)(1)+(0,25)(0,8)\}=0,8775 \\
& \text { A4 }=\{(0,30)(1)+(0,15)(1)+(0,05)(0,75)+ \\
& (0,25)(1)+(0,25)(1)\}=0,9875 \\
& \text { A5 }=\{(0,30)(0,8)+(0,15)(1)+(0,05)(1)+ \\
& (0,25)(1)+(0,25)(0,8)\}=0,89
\end{aligned}
$$

Nilai terbesar ada pada A4, sehingga alternatif A4 adalah rekomendasi alternatif dosen dengan nilai tertinggi.

\section{Context Diagram (DFD Level 0)}

Contextdiagram secara umum menggambarkan keseluruhan sistem pendukung keputusan penilaian proses belajar mengajar. Semua entitas eksternal yang ditunjukkan pada diagram konteks berikut aliran-aliran data utama menuju dan dari sistem. Secara detail dapat dijelaskan pada Gambar 3.

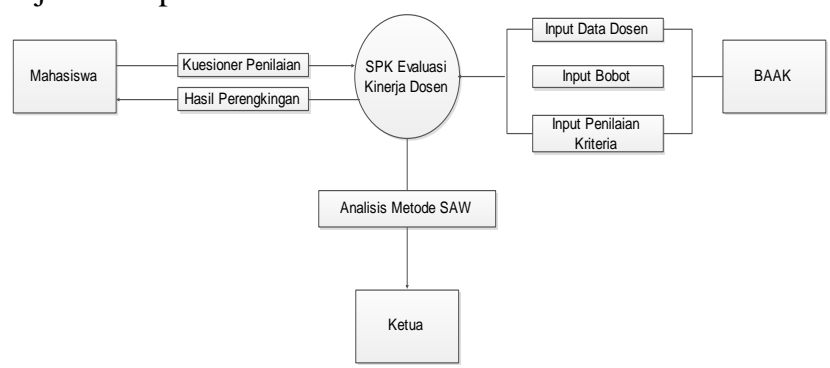


Gambar 3.Context Diagram SPK Evaluasi Kinerja Dosen

Contextdiagram di atas adalah gambaran secara umum dari sistem pendukung keputusan penilaian proses belajar mengajar, data-data yang masuk diolah oleh sistem agar dapat menghasilkan informasi yang digunakan sesuai dengan kebutuhan.

\section{Rancangan Sistem Menu}

Rancangan untuk sistem menu dapat dilihat seperti Gambar 4. Rancangan sistem menu menjelaskan tentang susunan menu utama sampai dengan submenu yang diimplementasikan dalam sistem ini. Rancangan ini memberikan gambaran lebih jelas tentang bagimana kontrol program dalam sistem ini..

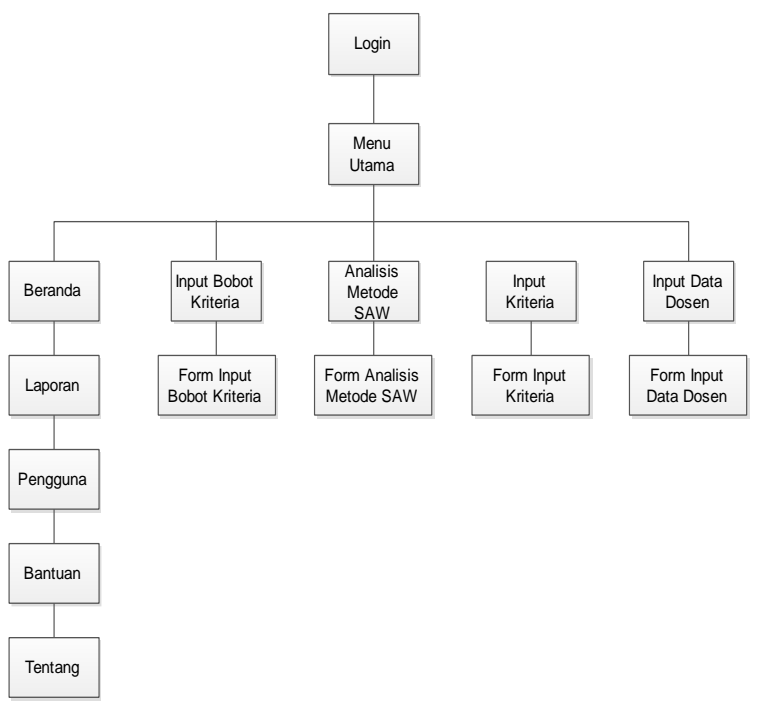

Gambar 4.10 Rancangan Sistem Menu

\section{E. Pengujian}

Tahap selanjutnya setelah analisa dan desain sistem, adalah melakukan pengujian terhadap sistem. Metode blockbox digunakan untuk menguji sistem ini. Metode pengujian akan membandingkan dua cara perhitungan yakni dengan cara manual dan menggunakan sistem, apabila kedua perhitungan ini menunjukan hasil yang sama, maka sistem bisa dikatakan telah lolos uji, sesuai dengan tabel 3 .

Tabel 3Pengujian black box

\begin{tabular}{|c|c|c|c|}
\hline No & Pengujian & $\begin{array}{l}\text { Hasil Yang } \\
\text { Diharapkan }\end{array}$ & Hasil \\
\hline 1 & $\begin{array}{l}\text { Precondition: } \\
\text { Pengguna } \\
\text { membuka } \\
\text { aplikasi project. } \\
\text { Form login akan } \\
\text { ditampilkan } \\
\text { pengguna } \\
\text { memasukkan } \\
\text { username dan } \\
\text { password. }\end{array}$ & $\begin{array}{l}\text { Project akan } \\
\text { menampilkan } \\
\text { halaman utama } \\
\text { sistem dan } \\
\text { menampilkan menu } \\
\text { analisis sistem } \\
\text { pendukung } \\
\text { keputusan. } \\
\text { Kemudian sistem } \\
\text { akan menampilkan } \\
\text { laman sesuai } \\
\text { dengan keinginan } \\
\text { pengguna. }\end{array}$ & Diterima \\
\hline 2 & $\begin{array}{l}\text { Precondition } \\
\text { :project dibuka, } \\
\text { pengguna } \\
\text { melakukan } \\
\text { pendataan data } \\
\text { dosen }\end{array}$ & $\begin{array}{l}\text { Data dosen } \\
\text { disimpan }\end{array}$ & Diterima \\
\hline 3 & $\begin{array}{l}\text { Precondition: } \\
\text { project } \\
\text { dibuka,pengguna } \\
\text { melakukan input } \\
\text { kriteria bobot } \\
\text { penilaian dosen }\end{array}$ & $\begin{array}{l}\text { Data bobot kriteria } \\
\text { evaluasi kinerja } \\
\text { dosen disimpan }\end{array}$ & Diterima \\
\hline 4 & $\begin{array}{l}\text { Precondition: } \\
\text { project } \\
\text { dibuka,pengguna } \\
\text { melakukan input } \\
\text { penilaian hasil } \\
\text { kuesioner } \\
\text { evaluasi kinerja } \\
\text { dosen }\end{array}$ & $\begin{array}{l}\text { Data nilai } \\
\text { kuesioner kriteria } \\
\text { evaluasi kinerja } \\
\text { dosen disimpan }\end{array}$ & Diterima \\
\hline 5 & $\begin{array}{l}\text { Precondition: } \\
\text { project } \\
\text { dibuka,pengguna } \\
\text { melakukan } \\
\text { perhitungan } \\
\text { penilaian hasil } \\
\text { kuesioner } \\
\text { evaluasi kinerja } \\
\text { dosen dengan } \\
\text { metode SAW }\end{array}$ & $\begin{array}{l}\text { Data hasil nilai } \\
\text { perengkingan } \\
\text { kriteria evaluasi } \\
\text { kinerja dosen } \\
\text { disimpan }\end{array}$ & Diterima \\
\hline
\end{tabular}

F. Tabel Perbandingan Nilai $S A W$

Berikut adalah sampel perbandinganantar perhitungan manual dan perhitungan yang dilakukan 
oleh sistem dan sampel ini dari beberapa dosen yang dinilai.

Tabel 4Perbandingan nilai SAW

\begin{tabular}{|c|l|c|c|}
\hline $\begin{array}{c}\text { N } \\
\mathbf{0}\end{array}$ & \multicolumn{1}{|c|}{ Nama } & $\begin{array}{c}\text { Nilai } \\
\text { Perhitung } \\
\text { an } \\
\text { Manual }\end{array}$ & $\begin{array}{c}\text { Nilai } \\
\text { Perhitung } \\
\text { an } \\
\text { Program }\end{array}$ \\
\hline 1 & Dosen 1 & 0,8875 & 0,95 \\
\hline 2 & Dosen 2 & 0,875 & 1,085 \\
\hline 3 & Dosen 3 & 0,8775 & 0,94 \\
\hline 4 & Dosen 4 & 0,9875 & 1,1 \\
\hline 5 & Dosen 5 & 0,89 & 1,083 \\
\hline
\end{tabular}

\section{BAB V KESIMPULAN DAN SARAN}

Kesimpulan

Dari hasil penelitian yang sudah dilakukan pada STMIK Bina Mulia Palu, maka dapat diambil kesimpulan bahwa Sistem Pendukung Keputusan Evaluasi Kinerja Dosen telah selesai dibuat dan dapat diterapkan sebagai pengolahan data secara komputerisasi. Yang dapat membantu bagian BAAK dalam memutuskan dosen terbaik dari yang terbaik dan melihat seberapa besar kinerja dosen dalam proses perkuliahan, serta dalam pembuatan laporannya.

\section{Saran-Saran}

Setelah menguraikan beberapa kesimpulan pokok tersebut diatas, berikut ini kami akan mengajukan masukan-masukan dalam bentuk saran-saran yang akan datang. Adapun saran-saran yang dimaksud adalah sebagai berikut :

1. Kepada BAAK STMIK Bina Mulia Palu untuk dapat menerapkan sistem pendukung keputusan pada bagian BAAK guna memperoleh keuntungan yang sudah dijelaskan pada kesimpulan diatas.
2. Dengan adanya Sistem Pendukung Keputusan yang berbasis database diharapkan menjadi motivasi untuk menerapkan dan mengembangkan teknologi informasi untuk masa yang akan datang. Termaksud penggunaan TI yang terpusat dalam penyajian Sistem Pendukung Keputusan pada STMIK Bina Mulia Palu.

\section{REFERENCE}

[1] Mulyadi, "Sistem Perancangan dan Pengendalian Manajemen," in 3, 2007.

[2] S. Kusumadewi and I. Guswaludin, "Fuzzy MultiCriteria Decision Making,” Media Inform., 2005.

[3] Ifo Wahyu Pratama, "Sistem Pendukung Keputusan Evaluasi Kinerja Dosen dengan Metode Technique For Order By Similarity To Ideal Solution ( Topsis ) \& Preference Ranking Organization For Evaluation ( Promethee )," J. Cendekia, 2018.

[4] L. Amsir, A. R. Manga, and H. Harlinda, "Penerapan Metode Simple Additive Weighting (SAW) dalam Penentuan Fakultas Terbaik," Pros. SAKTI (Seminar Ilmu Komput. dan Teknol. Informasi), vol. 3, no. 2, pp. 141-147, 2019.

[5] S. Syam, "Sistem Pendukung Keputusan Kinerja Dosen Menggunakan Metode Weighted Product ( Studi Kasus: Fakultas Teknik Univesitas Islam Syekh-Yusuf Tangerang )," Unistek, vol. 5, no. 1, pp. 12-16, 2018.

[6] T. D. Rachmawati, Penilaian Kinerja Profesi Guru dan Angka Kredit, 1st ed. Yogyakarta: Diva Media, 2013.

[7] I. Ghozali, Aplikasi Analisis Multiverat Dengan Program SPSS. 2013.

[8] R. A.S and M. Shalahuddin, Rekayasa Perangkat Lunak Terstruktur dan Berorientasi Objek. Bandung : Informatika. 2015. 